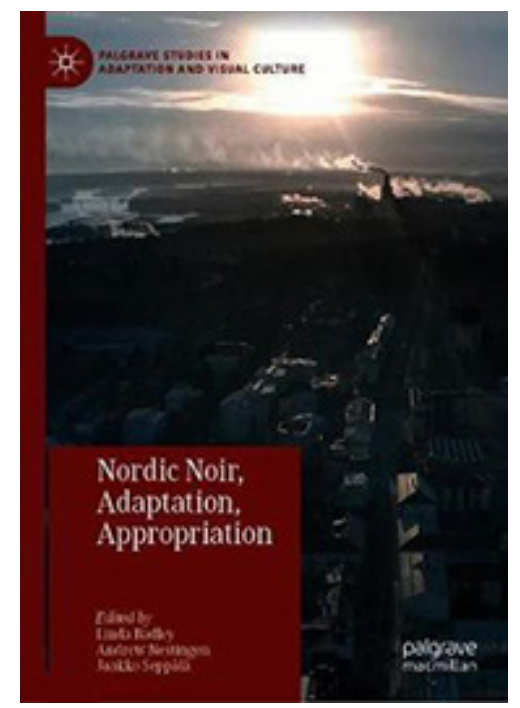

\section{NORDIC NOIR TAIPUU ERILAISIIN TARPEISIIN}

Linda Badley, Andrew Nestingen E Jaakko Seppälä (toim.) (2020)

Nordic Noir, Adaptation, Appropriation. Palgrave Macmillan, 336 s.
Nordic noiria on tutkittu viime vuosina paljon. Erityisesti tanskalainen televisiotutkimus on saanut uutta nostetta maan draamasarjojen kansainvälisen menestyksen myötä. Kyse ei kuitenkaan ole vain pohjoismaisesta ilmiöstä, sillä Nordic noirista on kasvanut käsite, jota hyödynnetään audiovisuaalisten sisältöjen ja alueiden brändäämisessä yli maa-, välineja genrerajojen. Nordic Noir, Adaptation, Appropriation tarttuu tähän monimuotoisuuteen ja lähestyy Nordic noiria nimenomaan sovittamisen (adaptation) ja omaksumisen (appropriation) näkökulmista.

Televisiotutkimuksessa adaptaation käsitettä käytetään pääasiassa kahdessa merkityksessä. Adaptaatiotutkimus on perinteisesti viitannut tutkimukseen, joka tarkastelee kirjojen ja muiden tekstien sovittamista audiovisuaalisten teosten muotoon eli sisältöjen siirtymistä mediumista toiseen. Television ohjelmaformaattien tutkimuksessa adaptaatio puolestaan merkitsee kulttuurista siirtymää, kun tietyllä kulttuurialueella tuotettu televisio-ohjelma toisinnetaan toisessa kulttuurissa.

Vaikka formaattisopimukset määrittelevät usein tarkat rajat formaattiadaptaatioille, on ohjelmien sisällöllinen ja tuotannollinen muokkaaminen nykyisessä televisiokulttuurissa enemmän sääntö kuin poikkeus. Teknologisen konvergenssin, uusien jakelualustojen ja monimediallisten tuotantojen myötä näiden kahden adaptaatio-määritelmän väliset rajat ovat liudentuneet. Tämä näkyy myös Nordic Noir, Adaptation, Appropriation -teoksen teksteissä. Vaikka johdannossa painottuu adaptaatiotut- kimuksen näkökulma, tarjoavat adaptaation ja appropriaation käsitteet kirjoittajille mahdollisuuden laventaa näkökulmaa Nordic noirin transkulttuuriseksi ja intermediaaliseksi tarkasteluksi (s. 5).

Kuten teoksen johdannossa todetaan, Nordic noirin historia voidaan itsessään nähdä varhaisempien rikostarinoiden omaksumisena ja muokkaamisena uusiin tarpeisiin. Sisällöllisen mukautuminen prosessi ei kuitenkaan pysähdy mediatekstin julkaisemiseen. Rikosromaanin kääntäminen toiselle kielelle edellyttää niin ikään kulttuurista neuvottelua, ja romaanin sovittaminen elokuvaksi tai televisiosarjaksi ja sarjan toisintaminen eri kulttuurissa lisäävät adaptaatioon vielä lukemattomia uusia kerroksia. Adaptaation käsite ei myöskään rajaa tarkastelua mediatekstin tasolle. Teoksen esimerkit osoittavat, että adaptaatiolla voidaan viitata vaikkapa televisiosarjan tuotantoryhmän tapaan omaksua uusia tuotantomalleja tai alueellisen tuotantokulttuurin mukautumiseen tietyntyyppisten sisältöjen tuotantoon.

Nordic noir on siis monenlaisiin tarpeisiin mukautuva ja jatkuvasti muuttuva käsite. Tämä joustavuus tekee Nordic noirista kuitenkin ongelmallisen juuri adaptaation käsitteen kannalta. Teoksen toimittajien mukaan Nordic noirille on ominaista kyky sopeutua erilaisiin paikkoihin, maihin ja kulttuureihin ja olla jatkuvassa muutoksen prosessissa. Nordic noir ei myöskään ole genre, vaikka sillä onkin sukulaissuhteita tiettyjen genrejen kanssa. (S. 5-6.) Adaptaatio kuitenkin edellyttää jotain, josta lähdetään liikkeelle - jotain, jota voidaan 
muokata. Mitä siis itse asiassa sovitetaan ja muokataan, kun kyseessä on Nordic noirin adaptaatio ja appropriaatio? Teoksen toimittajat huomauttavat, että Nordic noir haastaa perinteisen adaptaation rajat ja vertailun alkuperäisen ja mukaelman välillä (s. 7).

Pohdintaa voisi viedä vielä hieman pidemmälle: jos Nordic noir on itsessään saippuamaisen liukas käsite, missä kulkee Nordic noirin ja adaptaation raja? Onko ylipäätään mahdollista erottaa, milloin adaptaation prosessi alkaa ja milloin se loppuu? Kattavatko adaptaation ja appropriaation käsitteet loputtoman toistamisen, kierrättämisen ja muokkaamisen vai onko ne syytä korvata jossain vaiheessa muilla, paremmin kuvaavilla käsitteillä? Näihin kysymyksiin teoksen artikkelit ehdottavat useita erilaisia vastauksia. Esittelen tuonnempana muutamia tekstejä, joista esimerkiksi Pietari Käävän artikkeli määrittelee aineistonsa mediatekstit ei-Nordic noiriksi, vaikka niiden parateksteissä Nordic noirin adaptaatio onkin keskeisessä roolissa. Luis M. García-Mainar puolestaan tarjoaa ajatusta samankaltaisuuden verkostosta vaihtoehdoksi adaptaatiolle ja nostaa siten esiin adaptaation käsitteen riittämättömyyden.

Teos on jaettu väljän temaattisesti kolmeen osaan: keskusta/periferia, samankaltaisuus/ erilaisuus ja kerronta/tyyli. Massiiviseen teokseen sisältyy yhteensä 16 artikkelia. Suurin osa teoksen luvuista keskittyy mediatekstien - lähinnä televisiosarjojen ja elokuvien - analyysiin. Kiinnostavimmat kontribuutiot Nordic noir -tutkimukseen löytyvät kuitenkin artikkeleista, jotka tarkastelevat ilmiötä laajemmasta perspektiivistä.

Pietari Kääpä analysoi luvussa seitsemän televisiosarjoja, jotka eivät varsinaisesti ole Nordic noiria, mutta joita brändätään ja markkinoidaan Nordic noir -kytköksillä. Käävän aineistona ovat paratekstit eli varsinaiseen sisältöön liittyvä markkinointi- ja muu materiaali (s. 114). Parateksteissä käydään kulttuurista neuvottelua Nordic noirin omaksumisesta brittiläiseen kontekstiin. Kääpä osoittaa, että varsinaisten Nordic noir -sarjojen lisäksi myös muut sarjat voivat hyödyntää sille ominaisia elementtejä. Nordic noir -viittauksilla voidaan rakentaa esimerkiksi prestiisi-ohjelmiston kulttuurista pääomaa tai lisätä kaupallisuutta paikallisiin sisältöihin. Käävän artikkeli osoit- taakin erinomaisesti, miten joustava ja monikäyttöinen Nordic noir käsitteenä on.

Luvussa yhdeksän Luis M. García-Mainar puolestaan tarkastelee adaptaatiota perinteisten lähteen ja lopputekstin välisten suhteiden ja tietoisen tekijyyden yli monimutkaisina kulttuurisen kanssakäymisen verkostoina, jotka ilmenevät temaattisen ja esteettisen samanaikaisuuden muodossa. García-Mainarin aineistona ovat ruotsalainen Wallander-sarja, brittiläinen Tinker Tailor Soldier Spy -elokuva, amerikkalainen rikossarja The Americans, romanialainen elokuva Politist, adjectiv ja espanjalainen rikosdraamasarja Mar de plástico. Näiden mediatekstien väliltä voidaan jäljittää sellaisia samankaltaisuuksia, joita "viralliset" viittaussuhteet eivät selitä. García-Mainarin ajatus samankaltaisuuden verkostoista laajentaakin kiinnostavalla tavalla aiempia teorioita muun muassa genrestä, intertekstuaalisuudesta, adaptaatiosta ja kulttuurisesta neuvottelusta.

Luvuissa 11 ja 15 adaptaatio siirtyy tekstien tasolta tuotannon tasolle. Olof Hedling tarkastelee artikkelissaan, miten Wallanderin ja Sillan menestys johti niiden tuotantoalueen, Skånen, brändäämiseen tuotantohubina ja turistikohteena sekä alueen palvelu- ja elämystalouden aktivoitumiseen (s. 197). Adaptaation käsite laajenee siten viittaamaan siihen, miten paikallista populaarikulttuurin ilmiötä hyödynnetään taloudellisen rakennemuutoksen edistämisessä. Hedling kytkee artikkelissaan Nordic noirin kehityksen yhteen luovan teollisuuden nousun kanssa. Nordic noirin hyödyntämistä tietyn alueen brändäämisessä on tutkittu aiemminkin, mutta Hedlingin artikkelin ansiona on ilmiön sitominen laajempaan historialliseen viitekehykseen ja adaptaation käsitteen soveltaminen ilmiön analyysiin av-teollisuuden tasolla.

Kim Toft Hansen puolestaan tarkastelee Nordic noirin vaikutusta globaalien suoratoistopalvelujen (HBO, Netflix) draamatuotantoon. Virallisten formaattisopimusten sijaan myös Hansen on kiinnostunut epäsuorista vaikutteista, jotka näkyvät sarjojen tyylissä ja tarjoavat suoratoistopalvelujen eurooppalaisille tilaajille lokaaleja katsomiskokemuksia. Hansenin artikkeli on sijoitettu teoksen kerronta/tyyli-osaan, mutta se olisi voinut olla yhtä hyvin myös keskusta/periferia-osassa, sillä artikkeli tarjoaa konkreettisia esimerk- 
kejä siitä, miten televisio-ohjelmien virta ei enää kulje vain perinteisistä anglosaksisista televisiomaista muualle maailmaan vaan yhä useammin myös toiseen suuntaan.

Teos tarjoaa rikkaan ja monitasoisen kuvan Nordic noirista, ja venyttää samalla tietoisesti ilmiön ja sen tutkimuksen rajoja. Laajuudesta huolimatta formaattiadaptaatioiden tutkimus jää kirjassa melko vähäiseksi, vaikka aineistoa siihenkin olisi saatavilla runsain mitoin. Jatkuvassa muutoksen prosessissa olevat Nordic noirin ja adaptaation käsitteet tarjoavat jatkossakin kiinnostavia tutkimusaiheita, joihin voi ammentaa inspiraatiota tämän teoksen artikkeleista.

\section{Heidi Keinonen}

YTT, dosentti, mediatutkimus, Turun yliopisto 